\title{
Information Technology, Marketing Database and the Process of Integrated Marketing Communications (IMC): A Resource-Capability Nexus
}

\author{
Ayaz Ahmad ${ }^{1}$, Salniza Md. Salleh ${ }^{2}$, Selvan a/l Perumal ${ }^{3}$ \\ $1,2 \& 3$ School of Business Management, College of Business, University Utara Malaysia, \\ Sintok-Kedah, Malaysia \\ Email: ayaz_ahmad@oyagsb.uum.edu.my
}

\begin{abstract}
This study aims at identifying and conceptually linking Information Technology, Marketing Database and the IMC process in a resource paradigm. It also conceptually posits the mediated role of Marketing Database to further transmit the absorbed effect to the IMC process. Review of the past studies has been done to conceptually connect these resources and/or capabilities. This paper establishes different relationships to be further tested empirically for both the academia and industry professionals. The main contribution is to conceptually theorize all the three concept and linking them conceivably that were either missing or vague in the marketing communication literature. Further, it also provides a research avenue to seek the complementarity of such resources by utilizing the extended RBV theory. The theoretical framework proposed is based on past literature from the RBV and marketing communications literature positing some new structural paths beside certain previous linkage (s) if any.
\end{abstract}

Keywords: Antecedents, Resources, Capabilities, Integrated Marketing Communications, Marketing Database, Information Technology

\section{Introduction}

Facing the new realities of the markets, customers capabilities, emerging technologies, fragmented media situation and intense competition have attracted the academia as well as practitioners to have deeper insight of the firms' resources with respect to the firms' performance. In relation to marketing, academic scholars have continuously linking marketing resources with the firms' performance (e.g., Helfat et al., 2009; Katsikeas et al., 2016; Morgan, Vorhies, \& Mason, 2009; O’Cass \& Sok, 2014; Orr, Bush, \& Vorhies, 2011). The application of the RBV theory in the marketing studies have tremendously increased and 
still keep fast in conceptualizing different resources in the marketing domain and their related organization performance (Kozlenkova, Samaha, \& Palmatier, 2014), in the last two decades.

Despite extensive literature on resources and competitive advantage in the form of firms' performance, marketing or financial and economic performance, many research avenues are still vague, posing some unanswered queries and challenging issues, which require further conceptual and empirical proofs for addressing. This study poses some queries regarding the use and development of some specific organizational resources and/or capabilities for the nourishment of other resource (s) of the firm i.e., the contemplating role of Information Technology (IT) as a capability and Marketing Database (MDB) as a resource of the firm to further aid in the Integrated Marketing Communication (IMC) process, in contrast to several scholarly studies focused on the firms' resources and capabilities with respect to their performance outcomes in the form of the firms' performance. Moreover, this study also theoretically poses the possible effects that might result because of deployment of one resource in combination to the other.

As far the theoretical underpinning is concerned, this study adopts the RBV perspective of the firm (e.g., Morgan et al., 2009; Orr et al., 2011; Vorhies, Morgan, \& Autry, 2009), for conceptualization of all the three constructs cited earlier and the nexus they develop. Consistent with the RBV perspective and conceptualization of the IMC process as a resource and/or capability of a firm, it is essential to seek an insight of the factor resources and capabilities that facilitate the IMC process. As a matter of fact, firms are required to undertake the IMC process in such a challenging environment where media has fragmented, consumers are more equipped with handy media, IT on its boom and information regarding customers is in abundance. It is focused on the discussion and philosophical foundation of the superior outcome in the form of other resources and capability rather a performance outcome in some subjective or objective financial, market and other form of results. It focuses on answering the question of how one resource help in development of another resource that may lead to firms' performance eventually.

In line with the aim and scope of this study, the study foremostly presents the conceptualization of IMC process as a capability. Followed by IMC conceptualization, it elaborates the nature of the IT and MDB in the RBV perspective. Finally, it discusses the nexus they develop with the IMC capability. 


\section{Integrated Marketing Communications (IMC)}

Research scholars from the field of marketing communications believe that appropriate IMC has become necessity of the day to connect the firms to their stakeholder (Duncan \& Mulhern, 2004; Kitchen \& Schultz, 2009; Kliatchko \& Schultz, 2014; Porcu, Barrio-García, \& Kitchen, 2012a; Schultz, Kim, \& Kang, 2014; Tafesse \& Kitchen, 2015). Effective IMC has thus evolved as an essential component of marketing, business and corporate level strategies. Despite the importance accrued to the IMC process in academic literature, this well-known concept is yet subject to several differing views and definitions of the IMC. Several scholars (Cornelissen \& Lock, 2000; Duncan \& Mulhern, 2004; Kitchen \& Schultz, 2009; Reid, Luxton, \& Mavondo, 2005; Schultz et al., 2014; Tafesse \& Kitchen, 2015) viewed IMC in different perspectives and defined it in different manners. Recent literature (Abimbola et al., 2012; Einwiller \& Boenigk, 2012; Tafesse \& Kitchen, 2015), witnesses the extended scope of IMC to corporate level planning and implementation, and several other organizational domains.

\section{Integrated Marketing Communications - A Resource Based View}

As discussed, several perspectives and definitions have come to the fore from the last two and a half decades. However, few of the definitions got prominence, where the rest of the definitions are the extensions of the existing definitions. The focus over here is to discuss the IMC definition as a business (Duncan \& Moriarty, 1997; Duncan \& Mulhern, 2004; Kliatchko, 2005, 2008), and strategic process (Einwiller \& Boenigk, 2012; Porcu et al., 2016; Porcu, del Barrio-García, \& Kitchen, 2012; Tafesse \& Kitchen, 2015), rather the elaboration and discussion on numerous definitions..

It is noteworthy that wider literature of marketing communications is agreed upon the fact that IMC has developed into a concrete concept or philosophy and a process of interrelated activities (Duncan \& Mulhern, 2004; Kliatchko, 2008; Kliatchko \& Schultz, 2014; Porcu et al., 2016; Schultz et al., 2014). Some definitions of IMC in the literature are narrowed in scope, considering the IMC process as an operational or tactical level activity or process. However, some scholarly authors (e.g., Einwiller \& Boenigk, 2012; Kerr \& Patti, 2013; Porcu et al., 2016; Schultz \& Schultz, 1998; Tafesse \& Kitchen, 2015) contemplate IMC as a strategic process entailing all the three levels of the firms. They defined IMC as a business process and broaden the scope of IMC by considering strategic level activities e.g., the vision and mission of a firm, business and corporate level objectives and strategies etc. 
Pakistan Journal of Humanities and Social Sciences, 6(4), 2018

This process based definition led the marketing academicians (e.g., Kerr \& Patti, 2013; Luxton, Reid, \& Mavondo, 2015) to look into the IMC process with the capability lens, may be for the first time in the marketing communications' literature. Their scholarly work is analogous to several marketing scholars (e.g., Day, 2011; Morgan et al., 2009; Ngo \& O'Cass, 2012; O'Cass, Ngo, \& Siahtiri, 2012, 2015; Orr et al., 2011; Vorhies et al., 2009) who coined the concept of marketing capabilities. In line with the arguments presented by scholarly authors (Kerr \& Patti, 2013; Luxton et al., 2015; O'Cass \& Weerawardena, 2010; Ratnatunga \& Ewing, 2005), IMC process is inferred as a strategic capability of the firm that combines different tangible and intangible resources and capabilities to have superior or an acceptable level of related outcomes e.g., campaign effectiveness, brand market performance etc.

Beside a business and strategic process, IMC has been established as a concept, philosophy or a way of thinking (e.g., Duncan, 1995; Schultz \& Kitchen, 2000). Consistent with the RBV perspective and based on the conceptualization of IMC as a management concept, thinking or approach, an attitude and a philosophy, IMC is considered to reside in the adopted marketing and business philosophy and reflected through the norms and values of the organization. More specifically, every decision of the firm i.e., operational, tactical and corporate level, circles around the marketing communications that results in the integration of marketing communications throughout the firm's strategies.

Consistent with the RBV, several marketing researchers (Hooley et al., 2005; Hult \& Ketchen, 2001; Ketchen, Hult, \& Slater, 2007; Morgan et al., 2009; Vorhies et al., 2009; Weerawardena, 2003), have established a strong link between marketing resources and a competitive advantage due to its VRIN criteria (valuable, rare, inimitable and nonsubstitutable). In this regard, IMC being a market-based asset and market related capability can produce better outcomes and better results for a firm possessing greater IMC capability of planning and deploying better IMC campaigns. This perspective of IMC as a capability is in line with market based resource definition of (Hooley et al., 2005), and specialized marketing capability (Vorhies et al., 2009).

However, it is worthy to mention that researchers often make an implicit assumption of 'outstanding' or somewhat a 'miraculous' outcome of the application of the RBV theory. In line with the arguments presented in the literature (Helfat et al., 2009), this study also avoids such kind of implied assumption for the expected outcomes rather an acceptable level of performance of resources and capabilities. 
In this specific scenario of viewing IMC as capability of both planning and deployment, this study focused on the development and deployment of the IMC capability in presence of IT as a resource and/or capability and MDB as a market-based resource. In addition, a conceptual relationship has been developed between IT and MDB through the underlying tenets of IT capability and phenomenon of a database.

\section{Antecedent Factors of IMC Capability}

Literature review of the articles in the field of IMC is fleet with several driving factors affecting the IMC process. Numerous scholars (Duncan \& Moriarty, 1998; Eagle \& Kitchen, 2000; Luck \& Moffatt, 2009; Madhavaram, Badrinarayanan, \& McDonald, 2005; Porcu, Barrio-García, \& Kitchen, 2012b; Reid et al., 2005), identified several driving factors and discussed their role in the IMC process. Some scholarly authors have grouped these driving factors in their proposed or conceptual IMC frameworks. For instance, Tafesse and Kitchen (2015) have combined several of organizational process that may affect the IMC process with different levels, integration modes, scope and the related outcomes. Their 'call for' scholarly work is focused on the overall integration of the IMC process at different levels, with different scope and modes of the organizational strategy. Many of these factors have been grouped in endogenous and exogenous factors, further elaborating their nature, relationships with IMC and the possible propositions. However, these antecedent factors are, still subject to empirical findings as well as the absence of literature of these factors and IMC in the RBV perspective is yet to be explored. This study considers two of these factors i.e., IT capability and MDB to conceptualize them in the resource-based perspective as well as conceptually seek their relationship with the IMC process as a capability. As a matter of fact, the role of IT and MDB in general, has been discussed in the literature (e.g., Brady, Saren, \& Tzokas, 2002; Shaw et al., 2001). However, a thorough understanding of the two, their nature, mutual relationship and role for IMC capability in the RBV context is missing in the literature.

\section{Information Technology - The Marketing Domain}

It is a known fact that information technology has gained substantial importance and influence in the field of strategic marketing to gain competitive advantage (Brodie et al., 2008; Carolina, 2014). Hence, it has become a necessity to integrate IT into strategic marketing strategies. Managers must know how best to strategically position the IT resource and/or capability in their organizational processes to maximize the strategic gains (Lin, 2007). On the contrary, several companies are still unclear about the significance of using IT in 
terms of relating it with their financial outcomes or the way in which it influences strategy and critical performance outcomes (e.g., Chae, Koh, \& Prybutok, 2014; Lin, 2007). This is also due to the fact that several studies that investigate IT capability and firm performance are unable to differentiate IT 'capability' from IT 'investments', and 'value creation' from 'profitability' (Lin, 2007). The main assumption has been that IT capability will create economic value, enhance profitability and productivity (Lin, 2007), which is a limited view of IT capability.

Thus, the concept of IT requires clarity as it may mean different to different people (Brady et al., 2002). Researchers have defined and operationalized IT according to the needs and purpose of the use of the definition (e.g., Koppes et al., 1991) and Braun (1998) cited in (Brady et al., 2002). In literature, IT has been considered as: an information provider, an infrastructure (including both hardware and software), a business process and systems (Koppes et al., 1991), and so forth. In relation to marketing, IT has been viewed and discussed in the literature e.g., applications of IT (internet, power point, database etc.), a marketing channel (to link with suppliers and distributors), as a medium of communication or promotion, a tool of interactive and relationship marketing etc. numerous researchers (Brady et al., 2002; Brodie et al., 2008). However, less is known about the particular application of IT as one of the critical components in marketing practices, particularly the marketing communications.

\section{Information Technology - A Resource Based View}

The RBV perspective views IT both as a resource and a capability e.g., (e.g., Brady et al., 2002; Buhalis, 1998; Chae et al., 2014; Lin, 2007; Mikalef \& Pateli, 2017; Tippins \& Sohi, 2003) and a source of superior advantage (Lin, 2007). Though, it accepted widely that IT resources contribute to firms' performance and future growth potential, however, the empirical results of the relationship between IT capability and firm performance are ambiguous and inconclusive (e.g., Chae et al., 2014; Mikalef \& Pateli, 2017; Tippins \& Sohi, 2003). This may be attributed to lack of understanding of 'how and whether' IT can create greater value, fast-tracked innovations in IT, possible effects of human resource-IT interaction, and the nature of IT capability itself as a tangible or intangible resource. Further, most of the IT related studies aim to determine or assess the impact of IT on firms' performance. Hence, they cannot explicitly, differentiate between IT Capability and related investments, and value creation from the firms' IT capability (Tippins \& Sohi, 2003). It is 
quite possible that the IT Capability may produce greater non-financial value that requires to be addressed.

Consistent with the RBV perspective and conceptualization made by Brady et al. (2002) , IT capability is the knowledge of IT infrastructure and use of IT objects to manage information with in a firm. This conceptualization entails three basic tenets; IT knowledge, IT infrastructure or objects (hardware and software), and IT operations or processes (Brady et al., 2002; Brodie et al., 2008; Liang, You, \& Liu, 2010; Su et al., 2013; Tippins \& Sohi, 2003).

These dimensions are mutually independent. However, they exhibit a cumulative picture by 'co-specialization or complementarity' of resources. It implies that a firm must be capable of utilizing IT knowledge and IT infrastructure in IT related operations. Theoretically posed, all the three dimensions require to co-exist to ascertain IT capability (Tippins \& Sohi, 2003). Many large firms with enough IT infrastructure, may not attain IT related abilities because of lacking IT related knowledge and personnel (Brady et al., 2002). Likewise, capable personnel may ascertain IT capability, but lack of infrastructure may restrict to do so. Hence, it can be inferred that the co-existence of these three dimensions is important for the IT capability.

\section{IT Capability and IMC Process}

Instead of focusing on technological aspects, this study considers IT as a resource and capability that aid in the IMC planning and implementation process parallel to the utilization of IT resource or capability in the other marketing domains by numerous authors (e.g., Brady et al., 2002; Brodie et al., 2008; Chae et al., 2014; Mikalef \& Pateli, 2017). Further, the focus is not on the value spent and earned by IT in organizations rather the way IT contributes to or complements the other capabilities of a firm through better management. Thus, the study models the contribution that IT makes to the IMC capability.

Both IT and IMC are interlinked primarily on the basis that central to IMC planning and implementation is the cross-functional coordination, as discussed and quoted by numerous legendary authors (e.g., Porcu, del Barrio-García, et al., 2012; Tafesse \& Kitchen, 2015). It is contended that in today's competitive business world, more effective and appropriate system for information flow is required otherwise timely and appropriate communication and coordination may not occur. This will hinder the planning process by slowing down as well as affecting the consistency of messages and decisions. It can be further contended that for an effective and efficient IMC planning and execution, appropriate market 
related information to be obtained, analyzed and disseminated for decision making (Jaiyeoba \& Amanze, 2014; Narver \& Slater, 1990). However, the whole process of acquiring, analyzing and dissemination of these information is not possible without utilizing the IT capability. Thus, it can be posited that IT capability must be in place as a support mechanism, if IMC planning and execution to be effective and efficient, indicating a direct relationship between the two capabilities. Based on the conceptualization of the IT as a capability, linkage between IT capability and IMC Capability can be proposed as below;

Proposition 1: Information Technology as a resource and capability will have a significantly positive effect on the IMC process.

\section{Marketing database}

A comprehensive database provides a base to the whole marketing mix activities. It keeps the marketers up to date with the customers related information to further devise marketing mix strategies (Hughes, 2005). In relation to marketing communications, it functions like the lifeblood while planning and implementing marketing campaigns. Tafesse and Kitchen (2015) argue that proper database system is expected to play a direct role in the integration strategy in relation to the target audience, communications' messages and the media channels etc. Putting simply a proper marketing database shall facilitate the marketing communication strategy and delivery of the relevant communication messages to the customer audience and other stakeholders by holding and disseminating well synchronized information through different, but appropriate marketing channels. In order to get optimal benefits of a marketing database, marketers are required to ensure that their marketing database contains accurate, complete and required information (Kotler, 2009).

In this connection, firms must be capable enough to gain insights of the targeted segments and utilizing further the information for the marketing strategies in general and communications in specific. However, the changing situation of the media have put challenges to the marketers in acquiring useful information and analyzing information for optimum utilization. As Peltier, Schibrowsky, and Schultz (2003) argue that firms in this changed paradigm rely not only on the traditional methods of collecting customer and market related information but also make use of the advanced methods and way to acquire information e.g., media channels' monitoring reports, media ratings, electronic surveys etc. Careful analyses of such information present sensible indications of geographic, demographics and especially the psychographic information. Hence, such information when utilized appropriately, offer advantages to the marketers while planning and implementing 
strategies. Several researchers (e.g., Preston, 2000) in the marketing domain are of the view that a marketing database must acquire information related to behavior of the target segments. Furthermore, several scholars (e.g., Chen, 2011; Lee et al., 2010; Lin, 2006; Zahay, Mason, \& Schibrowsky, 2009) argue that it is actually the psychographics that eventually directs and shape up the behavior of the individuals.

\section{Marketing Database - A Resource Based View}

In most simple words, a database is a pool of information or knowledge regarding customers. Peltier et al. (2003) conceptualized a proper database management system as 'the process of collecting customer data, integrating the data to form customer segments, and then using other data to build predictive models for categorizing other customers and prospects'.

The process of data or information collection results in customer related knowledge or insights that can be further utilized by the firms in the planning process. However, the information or data collected brings no fruitful results unless analyzed and utilized by the firms. Hence, a firm must be capable of obtaining useful information as well as utilizing the acquired information in the planning and implementation of the strategies. Consistent with these arguments, one can contend that marketing database is a comprehensive information management that combines different input resources i.e., information, acquisition of information, analytical input and dissemination or utilizing information, to give a certain output that can be further used in decision making in the marketing function in general and marketing communications in specific. Consistent with the RBV perspective of the firms and such customer related knowledge as a resource (e.g., Kearns \& Lederer, 2003), marketing database can be theorized as an intangible resource and capability that can obtain, analyze and utilize the information in a useful manner.

Based on the arguments presented and conceptualization of marketing database as a resource, it can be argued that marketing database shall be advantageous for the whole marketing mix in general and marketing communications in specific. The next section elaborates the relationship of marketing database to the IMC capability more specifically.

\section{Relationship of Marketing Database and IMC}

The association of a database with IMC may be added to the academic literature may for the first time, in the scholarly conceptual framework of IMC by (Nowak \& Phelps, 1994) followed by (Schultz \& Schultz, 1998). Rather to get more strengthened, the link between the two could not attract the attention of the academicians may be owing to an understood nature and important role it plays in planning and/or implementation of the marketing 
communications activities. The conceptualization of a customer database (Peltier et al., 2003) in relation to IMC elaborates that how the collected and stored information can be logically tied up to the IMC issues. They argue that such customer or marketing database exhibits clear picture and gives directions to the planer to make decisions accordingly, albeit in the RBV perspective i.e., how one resource complements the other.

Peltier et al. (2003) also highlighted the relationship by emphasizing the 'value', offered and communicated to target groups of consumers. Moreover, (Tafesse \& Kitchen, 2015) elaborate its linkage with the IMC in relation to the use of these information to plan the message as well as the preferred ways of accessing the consumer audience.

In line with such support, to become a 'smart' company in a true sense, a firm must be able to develop smart marketing communication's campaigns. Marketing databases facilitate IMC while planning the relevant activities by acquiring, storing, analyzing and providing required information that enables marketing decision makers to have deeper understanding of the target markets - implies who their customers are, their attitudes and behavioral patterns (Peltier et al., 2003; Zahay et al., 2004). According to scholarly integrative review of the IMC literature (Tafesse \& Kitchen, 2015), database is a support mechanisms that facilitate the IMC strategy.

Thus an IMC process supported by a smart marketing database is completely different, adopting an outside-in approach (Schultz \& Schultz, 1998) than the one that relies on the traditional and functional marketing communications (Peltier et al., 2003; Zahay et al., 2014; Zahay et al., 2004). With such an outside-in perspective, the IMC process is required to start with customers' needs, their attitude and behavior. The inbuilt feature of an appropriate marketing database is its analytical power to analyze what, why and how of the customers' attitudinal and behavioral patterns. For instance, the purchase history presents a vibrant picture of the behavioral patterns of the target markets. In relation to IMC planning and implementation, and consistent with the RBV perspective, a firm can utilize the features of a smart marketing database by developing the required communications in congruence to the 'what, why and how' of consumers' attitude and behavior.

Consistent with the arguments presented above, marketing database as a resource of a firm and IMC being a process and hence, a marketing related planning and deployment capability, it can be posited that a smart marketing database facilitate the IMC planning and execution process by offering a base to devise their activities. 
Proposition 2: Marketing Database as a resource of a firm will have a significant and positive effect on the IMC capability.

Yet, a positive linkage between MDB resource and IMC capability has been established theoretically. However, databases may not carry certain potential to acquire, store, analyze and disseminate useful information unless facilitated by the IT capability of a firm. Consistent with the arguments made to establish the link between IT and MDB, several scholars (e.g., Liang et al., 2010; Mikalef \& Pateli, 2017) are of the view that database utilize the IT related resources and capabilities to perform its functions. On the other hand, several studies (e.g., Brady et al., 2002; Ward, Taylor, \& Bond, 1996) on the role of IT state that improved IT capability may not be having a direct impact on performance. Some recent studies argue that IT may not be affecting the performance directly rather indirectly through some moderators and mediators or in presence of other resources and capabilities (e.g., Chae et al., 2014; Mikalef \& Pateli, 2017).

It is worthy to mention that these arguments seem to be in line with (Preacher \& Hayes, 2004, 2008) mediation approach that expresses no assumption of the direct relationship of IT capability and IMC capability. The study as whole remains consistent with the mediation approach defined in literature (i.e., Baron \& Kenny, 1986), by conceptually establishing a positive linkage between IT capability and IMC capability. Nevertheless, the proposition made in relation to mediation effect can be subject to empirical testing by adopting the 'segmentation approach' (Rungtusanatham, Miller, \& Boyer, 2014), introduced in the literature. Extending these arguments, it can be inferred that IT capability facilitate the database resource of the firm to further affect the IMC capability. In other words, IT capability beside a direct link with both MDB and IMC, carries the potential to affect the IMC capability through a strong mediation of MDB. In this regard, these relationships can by posited as following;

Proposition 3: IT capability has a positive and significant relationship with the Marketing Database.

Proposition 4: Marketing Database as a resource of a firm significantly mediates the relationship between IT capability and IMC process. 


\section{Conceptual Framework}

The previous discussion on the antecedents in the RBV context and their relationships with the IMC process provide conceptual foundation for the following relationships posited in this study.

Figure 1: Conceptual framework of the effects of IT Capability and Marketing Database on IMC Capability

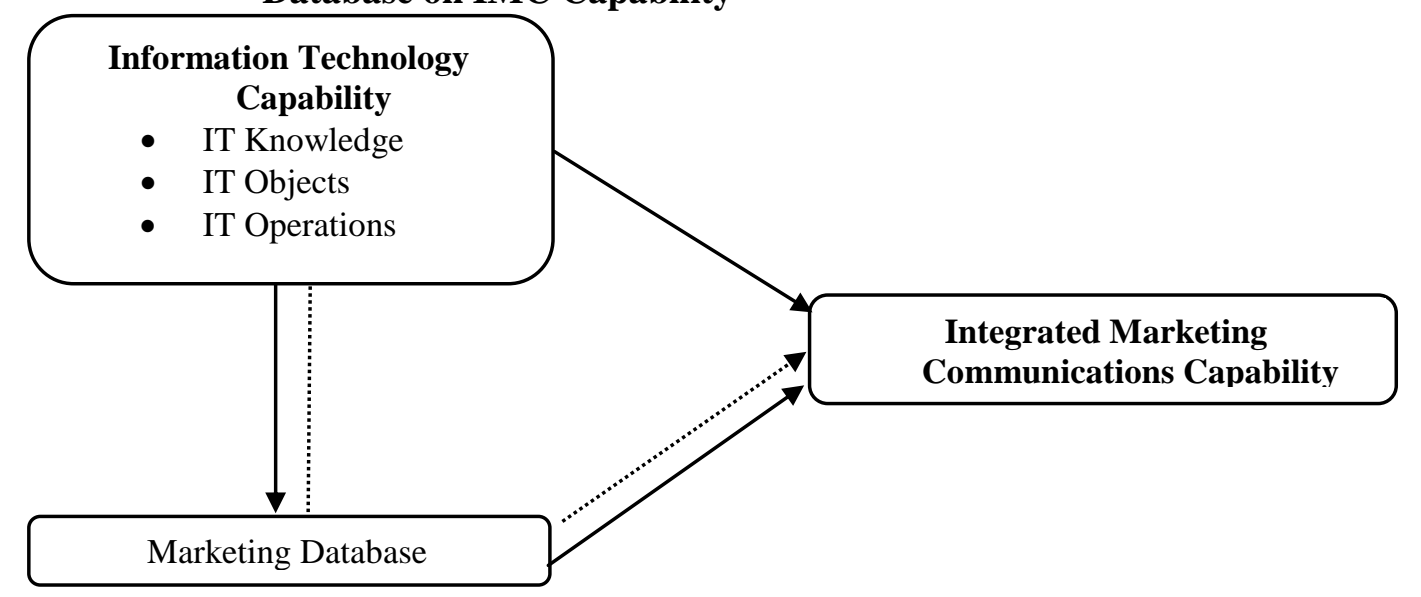

\section{Conclusion}

Prior discussion and conceptualization highlight the importance of resources and capabilities with respect to its vitality in the IMC process. In contrast to several studies focused on the resources' and capabilities' performance in the form of competitive advantage, this study focused on the underlying resources that may or may not be directly affecting the competitive performance of a firm rather they facilitate certain processes, mechanisms or other resources and capabilities that lead to superior value. The IMC literature, in this regard is vague for such kind of relationships. This paper provides a concrete base to further utilize these relationships for empirical testing and hence, their inclusion in the IMC planning and implementation. 


\section{References}

Abimbola, T., Trueman, M., Iglesias, O., Cornelissen, J., Thøger Christensen, L., \& Kinuthia, K. (2012). Corporate brands and identity: Developing stronger theory and a call for shifting the debate. European Journal of Marketing, 46(7/8), 1093-1102.

Baron, R. M., \& Kenny, D. A. (1986). The moderator-mediator variable distinction in social psychological research: Conceptual, strategic, and statistical considerations. Journal of personality and social psychology, 51(6), 1173.

Brady, M., Saren, M., \& Tzokas, N. (2002). Integrating information technology into marketing practice-the IT reality of contemporary marketing practice. Journal of Marketing Management, 18(5-6), 555-577.

Braun, E. (1998). Technology in context: Technology assessment for managers: Taylor \& Francis US.

Brodie, R., Brady, M., Brady, M., Fellenz, M. R., \& Brookes, R. (2008). Researching the role of information and communications technology (ICT) in contemporary marketing practices. Journal of Business \& Industrial Marketing, 23(2), 108-114.

Buhalis, D. (1998). Strategic use of information technologies in the tourism industry. Tourism management, 19(5), 409-421.

Carolina, L.-B. (2014). Information technology as a catalyst of relationship marketing within a global context. African Journal of Business Management, 8(22), 1066.

Chae, H.-C., Koh, C. E., \& Prybutok, V. R. (2014). Information Technology Capability and Firm Performance: Contradictory Findings and Their Possible Causes. MIS quarterly, 38(1), 305-326.

Chen, Y.-f. (2011). Profile of TV Drama Audience in Taiwan: A Case Study of EasternIntegrated Consumer Profile Database 2010.

Cornelissen, J. P., \& Lock, A. R. (2000). Theoretical concept or management fashion? Examining the significance of IMC. Journal of Advertising Research, 40(5), 7-7.

Day, G. S. (2011). Closing the marketing capabilities gap. Journal of marketing, 75(4), $183-$ 195.

Duncan, T. (1995). The concept and process of integrated marketing communication. IMC Research Journal, 1(1), 3-10.

Duncan, T., \& Moriarty, S. E. (1998). A communication-based marketing model for managing relationships. The Journal of marketing, 1-13.

Duncan, T. R., \& Moriarty, S. E. (1997). Driving brand value: Using integrated marketing to manage profitable stakeholder relationships: Irwin Professional Publishing.

Duncan, T. R., \& Mulhern, F. (2004). A White Paper on the Status, Scope and Future of IMC (from IMC symposium sponsored by the IMC programs at Northwestern University and the University of Denver). New YorN: McGraw-Hill.

Eagle, L., \& Kitchen, P. J. (2000). IMC, brand communications, and corporate cultures. European Journal of Marketing, 34(5/6), 667-686. doi:10.1108/03090560010321983

Einwiller, S. A., \& Boenigk, M. (2012). Examining the link between integrated communication management and communication effectiveness in medium-sized 
Pakistan Journal of Humanities and Social Sciences, 6(4), 2018

enterprises. Journal of Marketing Communications, 18(5), 335-361. doi:10.1080/13527266.2010.530055

Helfat, C. E., Finkelstein, S., Mitchell, W., Peteraf, M., Singh, H., Teece, D., \& Winter, S. G. (2009). Dynamic capabilities: Understanding strategic change in organizations: John Wiley \& Sons.

Hooley, G. J., Greenley, G. E., Cadogan, J. W., \& Fahy, J. (2005). The performance impact of marketing resources. Journal of Business Research, 58(1), 18-27.

Hughes, A. M. (2005). Strategic database marketing: McGraw-Hill Pub. Co.

Hult, G. T. M., \& Ketchen, D. J. (2001). Does market orientation matter?: A test of the relationship between positional advantage and performance. Strategic Management Journal, 22(9), 899-906.

Jaiyeoba, O., \& Amanze, D. (2014). Testing the Applicability of Narver and Slater's Market Orientation Concept and Firm Performance in Botswana Companies. Journal of Business Theory and Practice, 2(1), 1.

Katsikeas, C. S., Morgan, N. A., Leonidou, L. C., \& Hult, G. T. M. (2016). Assessing performance outcomes in marketing. Journal of marketing, 80(2), 1-20.

Kearns, G. S., \& Lederer, A. L. (2003). A resource-based view of strategic IT alignment: how knowledge sharing creates competitive advantage. Decision sciences, 34(1), 1-29.

Kerr, G., \& Patti, C. (2013). Strategic IMC: From abstract concept to marketing management tool. Journal of Marketing Communications, 21(5), 317-339. doi:10.1080/13527266.2013.786748

Ketchen, D. J., Hult, G. T. M., \& Slater, S. F. (2007). Toward greater understanding of market orientation and the resource-based view. Strategic Management Journal, 28(9), 961964. doi:10.1002/smj.620

Kitchen, P. J., \& Schultz, D. E. (2009). IMC: New horizon/false dawn for a marketplace in turmoil? Journal of Marketing Communications, 15(2-3), 197-204. doi:10.1080/13527260903003793

Kliatchko, J. (2005). Towards a new definition of integrated marketing communications (IMC). International Journal of Advertising, 24(1), 7-34.

Kliatchko, J. (2008). Revisiting the IMC construct: A revised definition and four pillars. International Journal of Advertising, 27(1), 133-160.

Kliatchko, J. G., \& Schultz, D. E. (2014). Twenty years of IMC: a study of CEO and CMO perspectives in the Asia-Pacific region. International Journal of Advertising, 33(2), 373. doi:10.2501/ija-33-2-373-390

Koppes, L. L., Trahan, W. A., Hartman, E. A., Perlman, B., \& Nealon, D. J. (1991). Researching the impact of computer technology in the workplace: a psychological perspective. Paper presented at the Management impacts of information technology.

Kotler, P. (2009). Marketing management: A south Asian perspective: Pearson Education India.

Kozlenkova, I. V., Samaha, S. A., \& Palmatier, R. W. (2014). Resource-based theory in marketing. Journal of the Academy of Marketing Science, 42(1), 1-21.

Lee, H.-K., Lee, J.-H., Kim, J.-t., \& Eui-Hyun, P. (2010). Method and system for recommendation based on locational and societal relation: Google Patents. 
Liang, T.-P., You, J.-J., \& Liu, C.-C. (2010). A resource-based perspective on information technology and firm performance: a meta analysis. Industrial Management \& Data Systems, 110(8), 1138-1158.

Lin, B.-W. (2007). Information technology capability and value creation: Evidence from the US banking industry. Technology in Society, 29(1), 93-106.

Lin, W.-J. (2006). Lifestyle and Media Usage of People in Taiwan-A Case Study of 2005 Shih Hsin Communication Database.

Luck, E., \& Moffatt, J. (2009). IMC: Has anything really changed? A new perspective on an old definition. Journal of Marketing Communications, 15(5), 311-325.

Luxton, S., Reid, M., \& Mavondo, F. (2015). Integrated marketing communication capability and brand performance. Journal of Advertising, 44(1), 37-46.

Madhavaram, S., Badrinarayanan, V., \& McDonald, R. E. (2005). Integrated marketing communication (IMC) and brand identity as critical components of brand equity strategy: A conceptual framework and research propositions. Journal of Advertising, 34(4), 69-80.

Mikalef, P., \& Pateli, A. (2017). Information technology-enabled dynamic capabilities and their indirect effect on competitive performance: Findings from PLS-SEM and fsQCA. Journal of Business Research, 70, 1-16.

Morgan, N. A., Vorhies, D. W., \& Mason, C. H. (2009). Market orientation, marketing capabilities, and firm performance. Strategic Management Journal, 30(8), 909-920. doi:10.1002/smj.764

Narver, J. C., \& Slater, S. F. (1990). The effect of a market orientation on business profitability. The Journal of marketing, 20-35.

Ngo, L. V., \& O'Cass, A. (2012). Performance implications of market orientation, marketing resources, and marketing capabilities. Journal of Marketing Management, 28(1-2), 173-187. doi:10.1080/0267257x.2011.621443

Nowak, G. J., \& Phelps, J. (1994). Conceptualizing the integrated marketing communications' phenomenon: An examination of its impact on advertising practices and its implications for advertising research. Journal of Current Issues \& Research in Advertising, 16(1), 49-66.

O'Cass, A., Ngo, L. V., \& Siahtiri, V. (2012). Examining the marketing planning-marketing capability interface and customer-centric performance in SMEs. Journal of Strategic Marketing, 20(6), 463-481. doi:10.1080/0965254x.2012.707675

O'Cass, A., Ngo, L. V., \& Siahtiri, V. (2015). Marketing resource-capability complementarity and firm performance in B2B firms. Journal of Business \& Industrial Marketing, 30(2), 194-207. doi:10.1108/jbim-05-2012-0087

O'Cass, A., \& Weerawardena, J. (2010). The effects of perceived industry competitive intensity and marketing-related capabilities: Drivers of superior brand performance. Industrial Marketing Management, 39(4), 571-581.

O'Cass, A., \& Sok, P. (2014). The role of intellectual resources, product innovation capability, reputational resources and marketing capability combinations in firm growth. International Small Business Journal, 32(8), 996-1018. 
Pakistan Journal of Humanities and Social Sciences, 6(4), 2018

Orr, L. M., Bush, V. D., \& Vorhies, D. W. (2011). Leveraging firm-level marketing capabilities with marketing employee development. Journal of Business Research, 64(10), 1074-1081.

Peltier, J. W., Schibrowsky, J. A., \& Schultz, D. E. (2003). Interactive integrated marketing communication: combining the power of IMC, the new media and database marketing. International Journal of Advertising, 22(1), 93-115.

Porcu, L., Barrio-García, S., \& Kitchen, P. J. (2012a). How Integrated Marketing Communications (IMC) works? A theoretical review and an analysis of its main drivers and effects.

Porcu, L., Barrio-García, S., \& Kitchen, P. J. (2012b). How Integrated Marketing Communications (IMC) works? A theoretical review and an analysis of its main drivers and effects/i Cómo funciona la Comunicación Integrada de Marketing (CIM)? Una revisión teórica y un análisis de sus antecedentes y efectos. Comunicación y sociedad, 25(1), 313.

Porcu, L., del Barrio-García, S., Alcántara-Pilar, J. M., \& Crespo-Almendros, E. (2016). Do adhocracy and market cultures facilitate firm-wide integrated marketing communication (IMC)? International Journal of Advertising, 1-21.

Porcu, L., del Barrio-García, S., \& Kitchen, P. J. (2012). How Integrated Marketing Communications (IMC) works? A theoretical review and an analysis of its main drivers and effects/i Cómo funciona la Comunicación Integrada de Marketing (CIM)? Una revisión teórica y un análisis de sus antecedentes y efectos. Comunicación y sociedad, 25(1), 313.

Preacher, K. J., \& Hayes, A. F. (2004). SPSS and SAS procedures for estimating indirect effects in simple mediation models. Behavior research methods, instruments, \& computers, 36(4), 717-731.

Preacher, K. J., \& Hayes, A. F. (2008). Asymptotic and resampling strategies for assessing and comparing indirect effects in multiple mediator models. Behavior research methods, 40(3), 879-891.

Preston, C. (2000). The problem with micro-marketing. Journal of Advertising Research, 40(4), 55-58.

Ratnatunga, J., \& Ewing, M. T. (2005). The brand capability value of integrated marketing communication (IMC). Journal of Advertising, 34(4), 25-40.

Reid, M., Luxton, S., \& Mavondo, F. (2005). The Relationship between Integrated Marketing Communication, Market Orientation, and Brand Orientation. Journal of Advertising, 34(4), 11-23. doi:10.1080/00913367.2005.10639210

Rungtusanatham, M., Miller, J., \& Boyer, K. K. (2014). Theorizing, testing, and concluding for mediation in SCM research: Tutorial and procedural recommendations. Journal of Operations Management, 32(3), 99-113.

Schultz, D. E., Kim, I., \& Kang, K. (2014). Integrated marketing communication research. The handbook of international advertising research, 455-483.

Schultz, D. E., \& Kitchen, P. J. (2000). A response to 'Theoretical concept or management fashion'. Journal of Advertising Research, 40(5), 17-21. 
Schultz, D. E., \& Schultz, H. F. (1998). Transitioning marketing communication into the twenty-first century. Journal of Marketing Communications, 4(1), 9-26.

Shaw, M. J., Subramaniam, C., Tan, G. W., \& Welge, M. E. (2001). Knowledge management and data mining for marketing. Decision support systems, 31(1), 127-137.

Su, Z., Peng, J., Shen, H., \& Xiao, T. (2013). Technological capability, marketing capability, and firm performance in turbulent conditions. Management and Organization Review, 9(1), 115-138.

Tafesse, W., \& Kitchen, P. J. (2015). IMC-an integrative review. International Journal of Advertising, 1-17.

Tippins, M. J., \& Sohi, R. S. (2003). IT competency and firm performance: is organizational learning a missing link? Strategic Management Journal, 24(8), 745-761.

Vorhies, D. W., Morgan, R. E., \& Autry, C. W. (2009). Product-market strategy and the marketing capabilities of the firm: impact on market effectiveness and cash flow performance. Strategic Management Journal, 30(12), 1310-1334.

Ward, J., Taylor, P., \& Bond, P. (1996). Evaluation and realisation of IS/IT benefits: an empirical study of current practice. European Journal of Information Systems, 4(4), 214-225.

Weerawardena, J. (2003). The role of marketing capability in innovation-based competitive strategy. Journal of Strategic Marketing, 11(1), 15-35. doi:10.1080/0965254032000096766

Zahay, D., Mason, C. H., \& Schibrowsky, J. (2009). The present and future of IMC and database marketing. International Journal of Integrated Marketing Communications, l(2), 13-30.

Zahay, D., Peltier, J., Krishen, A., \& Schultz, D. (2014). Organizational processes for B2B services IMC data quality. Journal of Business \& Industrial Marketing, 29(1), 63-74.

Zahay, D., Peltier, J., Schultz, D. E., \& Griffin, A. (2004). The role of transactional versus relational data in IMC programs: Bringing customer data together. Journal of Advertising Research, 44(01), 3-18. 